\title{
Relationship between Season and Semen Quality in Crossbred Bull Semen
}

\author{
M.M. Revathy ${ }^{*}$, R.S. Abhilash ${ }^{2}$, C. Jayakumar ${ }^{2}$, P.K. Magnus ${ }^{2}$, K. Raji ${ }^{3}$ and J. James ${ }^{4}$ \\ ${ }^{1}$ Department of Animal Reproduction, Gynaecology and Obstetrics, \\ College of Veterinary and Animal Sciences, Mannuthy, Thrissur-680651, India \\ ${ }^{2}$ Department of Veterinary Physiology, CVAS, Mannuthy, India \\ ${ }^{3}$ Managing Director, Kerala Livestock Development Board, India \\ *Corresponding author
}

\begin{abstract}
A B S T R A C T
Keywords

Motility, Viability, Abnormality, Acrosome integrity, Season

Article Info

Accepted:

22 July 2019

Available Online:

10 August 2019

The present study was envisaged to assess the effect of different seasons on semen quality of crossbred bull semen. Frozen semen samples produced from Kerala Livestock Development Board was collected from three different seasons of Kerala. Semen collected from six crossbred bulls of same exotic inheritance was selected. Maximum temperature and relative humidity significantly varied between different seasons $(\mathrm{p} \leq 0.05)$. However, Temperature Humidity Index (THI) and minimum temperature did not vary between seasons. After thawing, semen from each season was subjected to different in vitro tests like motility, viability, abnormality and acrosome integrity. Semen cryopreserved during summer season had significantly lower motility, viability, acrosome integrity $(\mathrm{p} \leq 0.05)$ and higher abnormality than rainy and post monsoon season. It can be concluded that semen cryopreserved during rainy season is having superior quality than other two seasons and post monsoon is intermediate between rainy and summer.
\end{abstract}

\section{Introduction}

The ability of spermatozoa to move through the female reproductive tract and the capacity to cause fertilization and subsequent embryo development will change as the quality of semen changes. The sperm quality can be indirectly measured through various laboratory techniques like assessment of motility, morphology, plasma membrane integrity, metabolic activity and the ability of intact acrosome to react (Morrell and Rodriguez-Martinez, 2009). The environment has both direct and indirect effects on semen quality. Temperature, humidity and rain fall in the area are having a direct effect on semen quality. The semen characteristics are also susceptible to factors like level of nutrition and management practices (Brown, 1994 and Snoj et al., 2013). The laboratory assessment of semen quality parameters is a convenient indirect way of detecting male fertility, without conducting an artificial insemination trial on each ejaculate.

Heat stress is having a negative impact on semen quality during all the stages of spermatogenesis. Since the total duration of 
spermatogenesis in bull is 61 days, the sperm quality parameters are more likely to be related to the climatic factors of one to two month before the date of semen collection (Sabes-Alsina, 2019). The semen quality is highly sensitive to even mild variation in the scrotal temperature. The effect of heat stress on the spermatogenic cell damage may be possible to observe only after two to four weeks of heat stress (Vogler et al., 1993) and it will take another six to twelve weeks to become normal (Kastelic et al., 1997 and Hansen, 2009). Therefore, the effect of climate on semen quality may be missed if the semen evaluation is made at an inappropriate time. The aim of the present study was to evaluate the effect of season on post thaw semen parameters like motility, viability, abnormality and acrosome integrity.

\section{Materials and Methods}

The different semen quality parameters such as post thaw motility, viability, abnormal morphology and acrosome integrity were analysed to identify the effect of season on male fertility. The seasons in Kerala were divided into rainy (June- September), postmonsoon (October- January) and summer (February- May) as per Biya (2011).

Six crossbred bulls of same exotic inheritance were selected from the bull station of Kerala Livestock Development Board (KLDB), Dhoni. Micro- climatic variables in the area were collected from nearest weather station (Integrated Rural Technology Centre, Mundur) during the study period. The variables collected were maximum temperature, minimum temperature and relative humidity from June 2017 to May 2018. From the collected data, Temperature Humidity Index (THI) in the area during the research period was calculated. Frozen semen straws of the selected bulls were collected from mid to end of each season and those straws having post-thaw motility of more than 50 per cent were included in the study. Semen quality analysis was carried out after thawing the straws in a water bath at $37^{\circ} \mathrm{C}$ for $30-45$ seconds.

A 3-4 mm diameter drop of semen was placed on a warm, clean, grease free glass slide, covered with a cover slip and examined under the phase-contrast microscope at 400X magnification. Motility was assessed based on progressive motile sperms. Sperm viability and morphology were assessed using EosinNigrosin staining technique. A moderately thick smear was prepared using stain and thawed semen. The smear was air dried rapidly at $37 \square \mathrm{C}$ on a slide warmer and a minimum of 200 sperms were counted from different microscopic fields under 100X oil immersion objective of a bright field microscope. The per cent of spermatozoa with normal and abnormal morphology were also assessed.

Seasonal influence of frozen crossbred bull semen on in vitro fertilization capacity was evaluated by subjecting the collected data to statistical analysis using SPSS version 24 software. Repeated measures ANOVA were used to compare the means. Means of microclimatic variables were compared using students one way ANOVA.

\section{Results and Discussion}

The results of the present investigation are summarized in Table 1 and 2. Maximum temperature was significantly higher during summer $(36.29 \pm 0.21)$ than post monsoon $(34.58 \pm 0.13)$ and rainy $(30.40 \pm 0.26)$. Relative humidity was significantly higher during rainy season $(81.56 \pm 1.36)$ than post monsoon $(61.10 \pm 1.37)$ and summer $(53.32 \pm 1.46)$ season. However, no significant difference was observed for minimum temperature and THI during the study period. 
Post thaw motility of frozen semen produced during rainy season $(47.50 \pm 1.70)$ was significantly higher $(\mathrm{p} \leq 0.05)$ than the semen produced during post monsoon $(42.50 \pm 1.12)$ and summer $(39.17 \pm 1.53)$ season. All the three seasons showed significant difference between each other. Semen produced during summer season have significantly lower motility than those of rainy $(\mathrm{p} \leq 0.01)$ and post monsoon season.

Viability of frozen semen produced during rainy $(56.17 \pm 1.07)$ season was nonsignificantly higher than the post monsoon $(53.67 \pm 0.33)$ and significantly higher $(\mathrm{p}$ $\leq 0.05)$ than the summer $(52.33 \pm 0.42)$ season. Viability of frozen semen produced during summer was significantly lower than that of rainy and post monsoon season.

Summer is causing significantly more sperm abnormalities than rainy and post monsoon season. Sperm abnormalities found during rainy $(4.5 \pm 0.76)$ and post monsoon $(5.83 \pm$
0.54) season were significantly lower ( $p$ $\leq 0.05)$ than summer $(7.67 \pm 0.33)$ season. There was no significant difference between the sperm abnormalities found in semen produced during rainy and post monsoon season. The abnormalities observed in the present study were head and tail defects. Abnormalities were within the permissible level of total 20 per cent, head and mid-piece defects were within 7 per cent (Minimum Standards for Production of Frozen Semen, National Dairy Development Board).

The number of sperms having intact acrosomes were higher during rainy $(89.67 \pm$ 1.43), intermediate during post monsoon $(87.83 \pm 0.83)$ and lower during summer $(86.33 \pm 0.71)$ season. A significant difference was observed ( $\leq 0.05$ ) between per cent of sperms having intact acrosomes during rainy and summer season. Acrosome integrity during post monsoon season was not having any significant difference between rainy and summer season.

Table.1 Mean \pm S.E. of microclimatic variables in the Palakkad area during the study period

\begin{tabular}{|l|c|c|c|c|}
\hline \multicolumn{1}{|c|}{ Season } & $\begin{array}{c}\text { Maximum } \\
\text { Temperature } \\
\left({ }^{\circ} \mathbf{C}\right)\end{array}$ & $\begin{array}{c}\text { Minimum } \\
\text { Temperature } \\
\left({ }^{\circ} \mathbf{C}\right)\end{array}$ & $\begin{array}{c}\text { Relative } \\
\text { humidity (\%) }\end{array}$ & $\begin{array}{c}\text { Temperature } \\
\text { Humidity Index }\end{array}$ \\
\hline Rainy & $30.40 \pm 0.26^{\mathrm{a}}$ & $24.32 \pm 0.09$ & $81.56 \pm 1.36^{\mathrm{a}}$ & $78.37 \pm 0.22$ \\
\hline Post-monsoon & $34.58 \pm 0.13^{\mathrm{b}}$ & $23.98 \pm 0.15$ & $61.10 \pm 1.37^{\mathrm{b}}$ & $78.64 \pm 0.28$ \\
\hline Summer & $36.29 \pm 0.21^{\mathrm{c}}$ & $24.43 \pm 0.17$ & $53.32 \pm 1.46^{\mathrm{c}}$ & $78.98 \pm 0.24$ \\
\hline p-value & $0.000^{* *}$ & 0.060 & $0.000^{* *}$ & 0.212 \\
\hline
\end{tabular}

Means with different superscripts differ significantly between groups

Table. 2 Effect of season on post thaw semen characteristics of crossbred HF bulls cryopreserved during different seasons

\begin{tabular}{|l|l|l|l|l|}
\hline \multicolumn{1}{|c|}{ Season } & \multicolumn{1}{c|}{$\begin{array}{c}\text { Motility } \\
(\text { Mean } \pm \text { S.E) }\end{array}$} & $\begin{array}{c}\text { Viability } \\
(\text { Mean } \pm \text { S.E) }\end{array}$ & $\begin{array}{c}\text { Abnormal } \\
\text { morphology } \\
(\text { Mean } \pm \text { S.E) }\end{array}$ & $\begin{array}{c}\text { Acrosome } \\
\text { integrity } \\
(\text { Mean } \pm \text { S.E) }\end{array}$ \\
\hline Rainy & $47.50 \pm 1.70^{\mathrm{a}}$ & $56.17 \pm 1.08^{\mathrm{a}}$ & $4.50 \pm 0.76^{\mathrm{a}}$ & $89.67 \pm 1.43^{\mathrm{a}}$ \\
\hline Post monsoon & $42.50 \pm 1.12^{\mathrm{b}}$ & $53.67 \pm 0.33^{\mathrm{a}}$ & $5.83 \pm 0.54^{\mathrm{a}}$ & $87.83 \pm 0.83^{\mathrm{ab}}$ \\
\hline Summer & $39.17 \pm 1.53^{\mathrm{c}}$ & $52.33 \pm 0.42^{\mathrm{b}}$ & $7.67 \pm 0.33^{\mathrm{b}}$ & $86.33 \pm 0.71^{\mathrm{b}}$ \\
\hline
\end{tabular}

Means with different superscripts differ significantly between groups 
Spermatogenesis is a continuous process in sexually mature male animal. Semen produced by animals are exhibiting a characteristic climatic pattern with respect to the quality and fertilizing ability. In the present study, summer season was found to have a significant effect on semen quality. The germinal cells during the early stages of spermatogenesis are vulnerable to high testicular temperature, due to its high mitotic activity. Some of the mechanisms that affected semen quality due to heat stress were DNA damage, generation of reactive oxygen species and reduction of sperm motility. These defects are expected to observe in the ejaculates around one to two month later (Sabes- Alsina et al., 2019). Extremes of temperature and humidity should be managed well to avoid the effect of heat stress.

All the conditions that cause elevated testicular temperature could reduce the sperms ability to maintain motility and viability after cryopreservation (Vogler et al., 1991). Highest temperature and lowest humidity in the research area was found during middle of March. The maximum temperature reached up to $40^{\circ} \mathrm{C}$ and the relative humidity observed was $32 \%$ during summer months. The semen collected for studying the effect of summer was during the period of April and May. Significantly reduced post thaw motility and viability observed in the present study might be due to the higher environmental temperature and lower humidity at the Dhoni region of Palakkad District in Kerala. High ambient temperature of $40^{\circ} \mathrm{C}$ and relative humidity of $35-45 \%$ could lower the sperm quality significantly. Bos taurus and crossbred bulls are more susceptible to heat stress than Bos indicus bulls (Kastelic., 2013). These extreme climatic conditions might have contributed to the reduction in semen quality during summer period in cross bred bulls selected for the study.
Significantly lower level of viable sperms during summer environment indicates the effect of heat stress to induce the death of sperms even before ejaculation (Bhakat et al., 2014). In the present study the percentage of abnormal sperms were also found to be higher during summer season. This result was in accordance with Bhakat et al., (2014), who observed significantly higher number of abnormal spermatozoa during summer season.

In the later stages of spermatogenesis, the sperm quality parameters expected to be affected are the sperm count, ATP concentration, fertilizing capacity and sperm membrane integrity (Sabes- Alsina et al., 2019). Crossbred animals having more than $50 \%$ of exotic blood inheritance level are more sensitive to the effect of heat stress than indigenous animals.

It can be concluded from the present investigation that summer season can significantly affect the motility, viability and acrosome integrity of spermatozoa. Also found that sperm abnormality was significantly higher during summer season.

\section{References}

Bhakat, M., Mohanty, T.K., Gupta, A.K. and Abdullah, M. 2014. Effect of season on semen quality of crossbred (Karan Fries) bulls. Adv. Anim. Vet. Sci. 2: 632637.

Biya, A.J. 2011. Assessment and alleviation of environmental stress on productive performance of rabbits. Ph.D thesis, Kerala Veterinary and Animal Sciences University, Pookode, 163p.

Brown, B.W. 1994. A review of nutritional influences on reproduction in boars, bulls and rams. Reprod. Nutr. Dev. 34: 89-114.

Hansen, P.J. 2009. Effects of heat stress on mammalian reproduction. Philosophical 
Trans. of the Royal Society B: Biological Sci. 364: 3341-3350.

Kastelic, J.P., Cook, R.B. and Coulter, G.H. 1997. Scrotal/testicular thermoregulation and the effects of increased testicular temperature in the bull. Vet. Clin. of N. Am. Food Anim. Prac. 13: 271-282.

Morrell, J.M. and Rodriguez-Martinez, H. 2009. Biomimetic techniques for improving sperm quality in animal breeding: a review. The Open Andrology J. 1: 1-9.

Sabes-Alsina, M., Lundeheim, N., Johannisson, A., López-Bejar, M. and Morrell, J.M., 2019. Relationships between climate and sperm quality in dairy bull semen: A retrospective analysis. J. of Dairy Sci. 102: 5623-
5633.

Snoj, T., Kobal, S. and Majdic, G. 2013. Effects of season, age, and breed on semen characteristics in different Bos taurus breeds in a 31-year retrospective study. Theriogenology. 79: 847-852.

Vogler, C.J., Bame, J.H., DeJarnette, J.M., McGilliard, M.L. and Saacke, R.G. 1993. Effects of elevated testicular temperature on morphology characteristics of ejaculated spermatozoa in the bovine. Theriogenology. 40: 1207-1219.

Vogler, C.J., Saacke, R.G., Bame, J.H., Dejarnette, J.M. and McGilliard, M.L. 1991. Effects of scrotal insulation on viability characteristics of cryopreserved bovine semen. $J$. of Dairy Sci. 74: 3827-3835.

\section{How to cite this article:}

Revathy, M.M., R.S. Abhilash, C. Jayakumar, P.K. Magnus, K. Raji and James, J. 2019. Relationship between Season and Semen Quality in Crossbred Bull Semen. Int.J.Curr.Microbiol.App.Sci. 8(08): 2480-2484. doi: https://doi.org/10.20546/ijcmas.2019.808.288 